\title{
Arts, Designs, and Textile Craft Art
}

\author{
Nanang Rizali \\ Faculty of Art and Design \\ Universitas Sebelas Maret, Indonesia \\ nanangrizali@staff.uns.ac.id
}

\begin{abstract}
In the discipline of fine arts, design development can be considered to be quite fast and even so flexible, that it is often difficult to establish its limitations. One of the results of this phenomenon is the variety of understanding and interpretations that is not much different from the reality of the design itself. Design, as an activity that demands creativity and imagination, offers an aesthetic element, so that in this term, design is an "art". And as an activity to find solutions to demands, design is a technological effort. In designing activities there are approaches that are oriented on design concepts and processes. Therefore, design involves human mind and effort in a unique combination to achieve certain goals. Design, in this case, is used to support an activity and its concept includes ideas and actions. Thus, there are several aspects related to designing activities, namely the aspects of aesthetic, materials, processes (technical), and functions. Therefore to comprehend further on the scope and understanding of designs, knowledge and various reviews are need in accordance with the related fields. Textiles, which have been known and made since the Neolithic era, are smooth and soft objects having aesthetic and technological elements. Up to now textiles have been developed into products that serve various functions and needs. As a medium of expression, textiles can be utilized in fields of Fine Arts which include fine art, design, and craft. This is very much determined by the approach being used, the way of thinking towards the end product of textile products. Thus the terms such as textile arts, textile design, and textile craft were established, although according to the history of the textile development, textiles in Indonesia originaly come from crafts that have artistic, design and local wisdom elements.
\end{abstract}

Keywords: Fine Art, Design, Craft, Creativity, Textile

\section{INTRODUCTION}

interpreting art include beauty, expressions of feelings, imagination, aesthetics, intuition and so on. According to American heritage quoted by Sugioko (1988), the absolute thing that must exist in art is skill, intelligence, expertise, agility, and proficiency in addition to the aestthetic characteristics which means beautiful, good, right, expensive, highly valuable and important. Thus art is too broad and difficult to be included under limitations, like science and religion that cannot be defined in simple terms. In the past, the word "Art" had different meaning and use with today's meaning and use. Originally the word art was an adjective equivalent with the word "fine" in various meanings such as elegant, thin, small, and etc.

Basically, art is a human nature granted by God for each activity that involves creative ability to manifest beauty, truth and goodness. Art as a creative process is an expression of mood, feeling and soul (Rader, 1986). An expression that has a meaning in art is an artistic expression derived from the quality of the soul image or the deepest essence of feeling. Therefore, only a few numbers of expressions are called the results of artistic activities, namely the expressions that make an object have expressive values. As a creative activity, art is very open to a variety of interpretations or misunderstandings, people).

Broadly speaking, art is classified into three groups, namely Performing Arts, Media Art, Fine Art (Visual Art). The three types of art employ the use of basic skills and beauty, as well as the arrangement of the words through the language elements. Fine Art uses visual language as a two-dimensional and three dimensional expressions with visual elements such as type, color, shape, texture, and etc. Fine Arts organize visualization through the principles of unity, harmony, balance, rhythm and proportion. The creative process and the implementation of art are based on aesthetic values and
Art is often interpreted with different meanings, thus it has multiple interpretations and various opinions. The basic interpretations that are commonly used

in so there is almost no limit that is tight enough to put a boundary to it. Another opinion states that art is beauty. It is an expression of human spirit and culture that contains and expresses beauty. Art was born from the deepest side of man driven by an artist's tendency towards beauty, whichever kinds of beauty (Shihab, 1996).

In general, each artwork is a combination of various elements and is constructed by characteristics. Some parts of an art form characteristics are based on spiritual ingenuity and local wisdom which are not only related to mere appearance (form), but also to its inner reality (meaning) in general as an integral whole. Art consists of four essential components, namely the basic purposes of art (aesthetics, logic, ethics, observance values), artistic creativity (views, concepts of ideas, insights), artistic work (creative processes, technical creation), and works of art (form, visualization, objects). The four components correspond to integral categories such as value, information, energy, and material. Thus the essence of art is inter-subjective and co-subjective dialogues that manifests into the four components of art. This implies the existence of vertical and horizontal relations which in the Islamic perspective is known as "hablum mi'nallah" (the relation between God and the servant/people) and "hablum minanas" (the relation among skills with the selection of materials that match their needs. Along with the art science and technology development, art has become a field of study in one faculty in accordance with the demands of life and the needs of society.

\section{AESTHETIC, TRUTH, AND GOODNESS VALUES IN FINE ART}

In a life that consists of social interaction, there are values that influence each other, namely ethics, logic, and aesthetics (Gazalba, 1997). Ethics determines the value of good or bad that is governed by religion. Logic 
determines true and false values that are ruled by science (knowledge). And aesthetics relate to the values of beauty and uglyness provided by art. In certain culture the system of values manifests and integrates in a simultaneous system of ideas, actions (attitudes), and works. Thus the work (of fine art) is the result of the realization of artists' ideas and attitudes with the underlying values.

Every object that is beautiful in nature and artwork creates a feeling of athmosphere and becomes an experience when someone is living the aesthetics. According to its terminology, aesthetic comes from the word "authesis" (Greek) which means sensory perception. Perception does not only involve the senses, but also psychophysics such as association, understanding, imagination, will, and emotion. In the beginning, aesthetics was a philosophy that dealt with an understanding of natural beauty, which later developed in the field of art. In its development to date, aesthetics has been interpreted as 'the core of art' which includes the selection and arrangement of the art elements (visual) and the way they are expressed.

The language of logic is generally used to explain the truth that is influenced by the human mind. In the reality of this experience the scientific method which is considered as the correct approach is used. In the scientific method, the causes and rational logical procedures are sought objectively toward various things both quantitatively and qualitatively. In a broader sense, the truth relates to the consideration of the efficiency and effectiveness of "production technology", economic and marketing calculations, as well as honesty. In addition, logic also relates to elements of service which include functional feasibility, security, comfort, usability, and the beauty of a product. Because each element has physical characteristics, strengths and forms that are in accordance with their inherent properties.

In general, ethics are rules, provisions or norms about what is good and bad, in addition to moral obligations or a collection of principles and values about the behavior of a community group including the community of professions. Understanding of good and bad is not just based on one's feelings (subjective), but also must be based on the insight of religiosity (religious beliefs). Even though human behavior is diverse and different, humanity (human nature) is always the same, that is, the conscience and reasoning activities. When reasoning has been able to absorb religious values, it will direct someone to behave politely, respectfully, wisely, tenaciously and creatively. Thus, through ethical values, a person is able to maintain his personality and identity as someone with proper morality.

Basically the form of art expression is a medium that functions to accommodate all contents of ideas. This form develops very dynamically and continues to move, so it is very open to all kinds of changes. However, because aesthetics are the core of art and sensory perceptions that are free from geographical and ideological boundaries, the basic framework of aesthetic forms will never change. The form of art expression has the opportunity to be used by a lot of content without reducing the values of beauty, truth, and goodness that they possess. In fine arts the things that must underlie and encourage the creation of work are the basic existence of the art purposes, namely the integration of the three values. Therefore, a work of art is not merely a visual form but should contain meaning, benefit and observance value when intended. Based on the reality of practice and work, there are two possibilities for fine art, to be considered essential and deviant.

\section{THE NATURE OF DESIGN: SCOPE, DEVELOPMENT AND UNDERSTANDING}

In several disciplines, especially in exact sciences, there are activities or processes called design. This refers to processes that are oriented towards active results in the form of man-made figures, structures or phenomena. The society development has become increasingly complex and raised many problems that must be approached and resolved interdisciplinary by paying attention to the development of theories and methods that can enhance interdisciplinary cooperation. Therefore it is clear that design has a broad space covering various disciplines. In some fields of exact sciences, the process, procedures and understanding of design are clearer, so that the implementation and products as the end result become clear. It is different in the discipline of art, where sometimes the presence of a design is so flexible, because design process in addition to considering the material, technical, and function aspects also takes aesthetic aspects into account.

In civil engineering discipline for example, there are creative activities that include planning and designing. Planning includes certain activities that must be done so that the final objectives or products can be achieved. This includes preliminary investigations, feasibility studies, detailed analysis, detailed implementation, fabrication in construction and monitoring as well as maintenance. This stage is closely related to the formulation of the goals and objectives to be achieved, including the consistency with the aspirations of community values, including the political, economic, socio-cultural, environmental, and technological fields. Designing includes the determination of specific objects from the final products, namely size, shape, color or known as the field of aesthetic.

Efforts to determine the limitations of design in the field of art are rather difficult, because design experts seem to be less concerned about the presence of their profession. This happened because in reality, the development of design profession that is so fast had provided an opportunity for design to live and develop in accordance with the times. In the practice of the design profession in the field of art, there is what is called a gray area, which is an area where interdisciplinary fields intersect or even overlap within the scope of their respective tasks. Before there is clarity about the meaning of design, the definition is assumed to be closely related to industry. Although the equipment used is very simple and the process is carried out without a systematic division of labor.

Design development that began in the 19th century to date began with functionalism in design or as an applied art. It was rooted and developed in the mid-19th century until today in which design has undergone many changes. In that era, the era of art and industry became the basis 
for Herbert Read artikel which described the limitations of pure art and applied art. In addition, the flow or Victorian style solidifies the institution between aesthetic value, form and function. Therefore, the term visual art and design was known, even in its development there is the term of craft art replacing art and design. The word design (in English) or design has a meaning that originally came from the Latin word designare which means marking. As a noun design means intention, will, plan, purpose, or can mean the design of patterns, ornaments, and compositions of works of art.

According to the experts who have been compiled in the book Design Method by J. Cristhopen Jones (1970), there are several definitions of design as follows:

- "A problem-solving activity directed to a goal or target" (Brunce Archer).

- "An optimistic solution to a number of real needs from a set of conditions" (Matchett).

- "An imaginative estimate of the facts that is available for future possibilities" (Page).

- "A creative activity to get results that are useful, new, and never been done before" (Reswich).

From the above definition, it is clear that design has a broad understanding and covers various aspects. In every design there are always various factors that must be fulfilled including the elements of physical and psychological services, namely that the design must be functional, safe, comfortable, and efficient.

Design can give values or meanings such as aesthetic, psychological, ergonomic and technological values. Therefore in an industry the notion of design is not merely a visual aspect, but also process of thinking on various aspects to achieve maximum and valuable results that are needed by the community. Thus, design has two meanings, namely as a noun that relies on the results of a design, and on the other hand design as a verb that relies on the creative process in producing a work. In the context of this understanding, the design can be utilized by all three fields of art namely fine art, design and craft. This is very much determined by the way to think, which starts from the basic thinking of the creation / design goals, ideas, and concepts and techniques.

\section{ART, DESIGN, AND TEXTILE CRAFT ART}

In the provision of Fine Arts Higher Education in Indonesia, there are three fields of study, namely Fine Art, Design, and Craft. In general, the Fine Arts sector has specifications of painting, sculpture, graphic arts, and ceramic arts, while the Design field has visual communication design, interior design, and product design. The Craft field has a textile craft study program, wood craft, metal craft, and etc. One of the craft fields is textiles, in Nusantara (the archipelago teritory of Indonesia), textile has been known since prehistoric times with a variety of fabrics that have a philosophical and aesthetic value. Textile is an item that comes from woven fiber or yarn, which is knitted into clothing or other necessities. Textiles are also medium for expression, crafts and arts, "the new textiles focuses on the individual work, in Craft, in Art and at the fringers at mainstream design" (Colcester, 1991: 10).
As a media for expression, textiles have the opportunity to be used as the basic material for producing works. Therefore, the term textile arts, textile design, and textile craft are known, although according to the history, textile development in Indonesia originaly comes from handicrafts that have art and design content. Just like in any arts, the arts of weaving and batik are inseparable from the skills and creativity of a craft artist who produces the works. Based on the relative comparison between the design art and textile craft with reference to aesthetic and technological elements, it can be seen that the aesthetic content has higher presentation compared to technology element in the field of textile arts and vice versa in the field of textile design. It is different from the textile craft, in which there is a relatively balanced ratio between aesthetic and technological aspects.

The embodiment of creative forms and compositions of textiles in addition to functional works can also be a medium of expression and fiction in the form of aesthetically non-functional exploration. Textile art is not merely a wall decoration or natural aesthetic element of the room, but also a medium for freedom and creative experimentation. It is inevitable that the emphasis on textile art is not only from the textile sector, but also from artists such as painters, sculptors, philosophers, and other artists. Even fashion designers have begun using and developing textile media and techniques in establishing their work. Thus textiles are objects that are soft and flexible with the senses of intuition, expressions of color, and psychological elements that ultimately bring beauty (aesthetics).

One of the textile artworks produced through woven structure designs of fibers or threads is called the fiber art. This type of artwork is similar to tapestry making skills by Middle Eastern craftsmen. In maintaining the existence of the art elements that are more concerned with artistic and aesthetic aspects, fiber art (tapestry) is developed through hand weaving techniques because various technical possibilities are the parts of aesthetic exploration with the emphasis on the expressions of form, color, and texture. Like textile fabric, tapestry has a base of woven structures in the form of horizontal and vertical constructions. The flexibility of achieving these shapes causes objects being worked on to show visual similarities similar to paintings.

Textile design as a process is one of the efforts to improve textile products in order to have a higher aesthetic and economic value. It is a creative process that considers various aspects, including material, technical, aesthetic functions and so forth to produce valuable items needed by the community. Therefore, textile design is one of the important elements of the integration of various aspects in the industry chain. Thus the product will have high quality and be more efficient, attractive, and comfortable at affordable prices for the public. As one of the links in the industrial chain, textile design should fulfill aspects of needs, functions, aesthetic appeal and marketing.

Basically designing is interpreting the needs, goals, and ideas of the users in accordance with the specifications of social and environmental technology and considering the usability that refers to the market and buyers. Thus to achieve the goal, textile design must 
consider various things, namely the target market, market share, product competition and buyers' attitudes and behavior. The target market is a group of buyers who are marketing targets that relate to the level of socioeconomic community groups, strata and locations in the environment. Market share is the location of the target market to determine segmentation concerning the age of education and the habit of owning or using the product. Competition is paying attention to the condition of similar products circulating in the market, including comparing them. The attitude and behavior of buyers is an effort to understand the acceptance of prospective buyers in the process of purchasing textile products.

In general, the term craft art is a combination of and a replacement for the term of art and design. Craft is closer to the term handy craft which is related to hobbies, while craft art is broader in terms of understanding and insight. In essence, craft art is a cultural object known as the ethnic art of the archipelago of Indonesia, which is philosophically and aesthetically charged and has certain functions. In addition to having a touch of art, there is also an element of design, namely the content in terms of usage. Despite the classification of applied art for art in use and pure art, there are art and design contents in craft art. Among the distinctive features of the craft art is the traditional meaning and historical element with the help of simple tools and the making process which is carried out for generations. In Indonesia, the development of craft has been known since the prehistoric times when the traditional ethnic group started producing craft art works in various forms.

One of Nusantara's craft art works is the textiles of various kinds that always adapt to the environment and preserve the traditions passed down for generations. Several types of crafts, especially the weaving art, batik art, connective arts, and Indonesian textile art are the branches of craft art that have been rooted in Indonesian culture for a long time. Their high quality of beauty can highlight Indonesian characteristics (Koentjaraningrat, 1985). The forms of patterns and variety of integrated textile decoration with manufacturing techniques, as well as the reflection of the background and content that inspire local culture, have made Indonesian traditional textiles not only beautiful but also fused with moral and customary values. It contains the symbols of philosophical trust and the concept of harmony in life, namely the balance between the life in the world and in the afterlife.

Every ethnic area in Indonesia has a variety of decorations and colors that are influenced by its sociocultural background. The differences in the elements of local traditional culture and the values of new civilizations have resulted in a variety of Indonesian textile craft. This has made Indonesia to be one of the largest (traditional) textile producing countries in the world. As according to Joseph Fisher that: "Indonesian has been the greatest producer of traditional fine textiles in the world. It is a rich, varied, creative, artistic, and complex tradition that existed for fifteen hundred years"(Fisher, 1979: 9). There are various types of amazing textiles with different technical materials, motifs and colors spread widely in the Indonesian archipelago. All of these are the work of art / craft art / design works created by tradition, a beauty full of diversity that has been growing since thousands of years ago.

\section{CONCLUSION}

Art, especially Fine Art as a universal visual language, is expected to have the capacity to be used as a means to encourage good deeds, and prevent disgraceful actions as wll as build a life of justice and morality. It is also hoped that art can develop and foster the feelings of subtlety, beauty and truth towards material-spiritual balance. Thus Arts with the fields of Fine Arts, Design and Craft Arts will be able to play its role in fulfilling the human life both physically and spiritually and provide physical and psychological satisfaction. Therefore reposition towards a more progressive role is required, namely as an agent of socio-cultural resistance. Art graduates should act not only as cultural heirs, but also as agents of cultural change.

In an effort to develop artistic knowledge, especially in Indonesia, various things need to be endeavored to ensure continuity in the past, present and future. This is in accordance with the nature of culture, that culture now is the result of the growth and development of social interaction in the past. The field of Fine Arts does not stand alone. It correlates with other related sciences such as history, anthropology, ethnography, sociology, and so on. Thus, a more open and integrated efforts are needed with insights that are not limited to visual studies, but to something that is beyond the reach of the eye (intangible transcendence), with the aim of achieving wisdom and awareness toward The Almighty, The Graceful and The One Most Beautiful.

Textile is an important cultural object serving as a clothing material throughout the world, which also acts as a body protection tool. It started with the functional purpose of clothing, and continues to grow more broadly included in its terminology. Textile functions have been developing into protectors, means of communication, identity, and complementary beauty. In relation to the clothing function, textile can provide the identities of people during interactions and recognize their social status, position or occupation. The link between textiles and clothing with people shows that clothing is people's secondary skin and that both people and textiles are the backbone of clothing. Thus the important role of of textiles and clothing does not only influence people's physicality, but also their spirituality.

\section{REFERENCES}

Clipson, Colin, 1989, Design for A Coming Age, Nagoya, Japan: ACID.

Colchester, Chloe, 1990, The New Textile, Trend \&Traditions, London, Thames and Hudson. Ltd.

Johnston, Meda Parker, \& Glen Kanfman, 1967, Design on Fatrics, New York: Van Nonstrand Reindhold Company.

Jones, J.Christopher, 1970, Design Methods, London: Jhon Wiley.

Koetjaramingrat, 1985, Kebudayaan Mentalis dan Pembangunan, Jakarta: PT Gramedia.

Lyle, Dorothy Siegent, 1978, Modern Textile, Canada: Jhon Willey \& Sons. Inc.

Rizali, Nanang, $\quad 1992$ 
Pengaruh Perubahan Desain Tekstil terhadap Perkembangan Mode dan Kecenderungan Pembeli”, Tesis Magister Seni Rupa dan Desain, Program Pascasarjana, Bandung: Institut Teknologi Bandung.

Robin, Leonard G., 1967, The Word of Fashion, London: A Departement of Harpen \& Row, Publisher Inc.
Sparke, Penny, 1987, Design in Context, New Yersey: Chartwell Books Inc.

Umar, H., 2003, Strategic Management in Action, Jakarta: Gramedia.

Wulandari, A., 2011, Batik Nusantara, Yogyakarta: Penerbit Andi. 